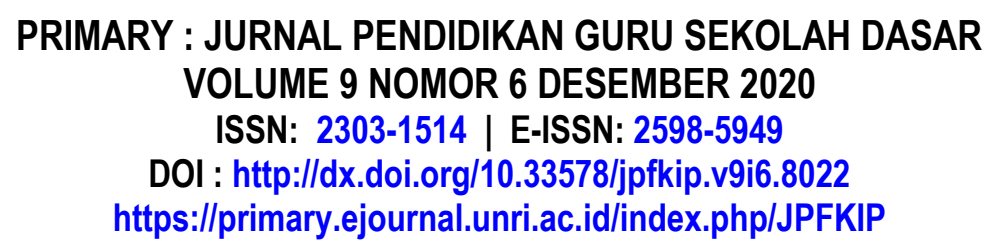

ISSN: 2303-1514 | E-ISSN: 2598-5949

DOI : http://dx.doi.org/10.33578/jpfkip.v9i6.8022

https://primary.ejournal.unri.ac.id/index.php/JPFKIP

\title{
THE EFFECTIVENESS OF USING DESIGNED COASTAL AREA MEDIA FOR MATHEMATICS LEARNING
}

\author{
Zuhri D ${ }^{1}$, Sehatta $S^{2}$ \\ 1,2 Universitas Riau, Pekanbaru, Indonesia \\ 'zuhri@lecturer.unri.ac.id, ${ }^{2}$ ssehatta@yahoo.com
}

\section{EFEKTIVITAS PEMBELAJARAN MATEMATIKA MENGGUNAKAN WILAYAH PANTAI YANG DIRANCANG MEDIA}

\begin{tabular}{|c|c|}
\hline ARTICLE INFO & ABSTRACT \\
\hline \multirow[t]{2}{*}{$\begin{array}{c}\text { Submitted: } \\
\text { 01 September } 2020 \\
01^{\text {th }} \text { September } 2020\end{array}$} & $\begin{array}{l}\text { Abstract: The meaning of numbers, often referred to as Number Sense, is very important for students to } \\
\text { understand especially in the elementary school. Correspondingly, elementary school students who are } \\
\text { new to numbers must be given a real experience as a means of building an understanding of the } \\
\text { meaning of numbers. Related to that, this study aimed to investigate the understanding of elementary } \\
\text { school students at grade I who were taught with the designed coastal area media. The subjects of this } \\
\text { study inclluded } 2 \text { elementary schools with a total of } 42 \text { subjects located on the coast. The purpose of this } \\
\text { study was to investigate the effectiveness of learning and its impact on number sense. The results of the } \\
\text { data analysis showed that the effectiveness of using designed coastal area media for mathematics } \\
\text { learning was in Good category. Moreover, the students' understanding of the meaning of numbers after } \\
\text { the treatment significantly increased by } 21.3 \% \text {. }\end{array}$ \\
\hline & Keywords: learning effectiveness, coastal area design media \\
\hline \multirow[t]{2}{*}{$\begin{array}{c}\text { Accepted: } \\
\text { 12 Desember } 2020 \\
12^{\text {th }} \text { December } 2020\end{array}$} & $\begin{array}{l}\text { Abstrak: Arti angka yang sering disebut dengan Number Sense ini sangat penting untuk dipahami oleh } \\
\text { siswa khususnya di Sekolah Dasar. Sejalan dengan itu, siswa sekolah dasar yang baru mengenal angka } \\
\text { harus diberikan pengalaman nyata yang mereka alami sebagai sarana untuk membangun pemahaman } \\
\text { tentang makna angka. Sehubungan dengan itu, penelitian ini bertujuan untuk mengetahui pemahaman } \\
\text { siswa sekolah dasar kelas I yang diajar dengan media pembelajaran desain wilayah pesisir. Subjek } \\
\text { penelitian ini terdiri dari } 2 \text { Sekolah Dasar dengan jumlah } 42 \text { mata pelajaran yang terletak di pesisir } \\
\text { pantai. Tujuan dari penelitian ini adalah untuk mengetahui efektivitas pembelajaran dan pengaruhnya } \\
\text { terhadap number sense. Hasil analisis data menunjukkan bahwa keefektifan pembelajaran matematika } \\
\text { dengan menggunakan media rancang bangun kawasan pesisir berada pada kategori baik dan } \\
\text { pemahaman siswa tentang makna angka setelah perlakuan meningkat secara signifikan sebesar } 21,3 \% \text {. } \\
\text { Kata kunci: Efektivitas Pembelajaran, Perancangan Media Wilayah Pesisir }\end{array}$ \\
\hline & $\begin{array}{l}\text { CITATION } \\
\text { Zuhri, D. \& Sehatta, S. (2020). The Effectiveness of Using Designed Coastal Area Media for } \\
\text { Mathematics Learning. Primary: Jurnal Pendidikan Guru Sekolah Dasar, 9(6), 891-899. DOI: } \\
\text { http://dx.doi.org/10.33578/jpfkip.v9i6.8022. }\end{array}$ \\
\hline
\end{tabular}

\section{INTRODUCTION}

Indonesia is known as a maritime country, which has 13466 islands and a coastline of 99093 $\mathrm{km}$ with its characteristics is working as fishermen, have low education levels, and a life of deprivation. Economic conditions such that encourage coastal communities of the view that to include the child into fishing is more important than going to school. This view will shackle throughout life if there is no effort to improve the human resources of coastal children. For that, we need a real effort to change the paradigm that underdevelopment and poverty can be minimized so that they will live more feasible. One such effort is to improve the quality of education by making improvements to learning so that coastal children are comfortable taking up their education.

In the 2013 curriculum, it is stated that learning activities are managed by applying a 
scientific approach, which starts from observing, asking, seeking information, reasoning, and communicating. Creativity to build such learning experiences is seen as more meaningful because, in addition to students playing an active role, it is also optimizing the use of more varied sensory devices. At the beginning of student learning activities namely observing, the curriculum recommends using students' real experiences as a learning context or setting. Such methods are seen as able to develop students' motivation and interest in learning because they can feel the benefits of learning. Thus for schools located in the coastal areas, the contexts used as material for student observation or design come from the coast such as fish, canoes/boats, nets, coconuts, etc. Then considering the intellectual development of students for the rest of elementary school children who are still at the stage of concrete, the use of context or patterned media environment will encourage their students are actively involved in building knowledge which leads to the acquisition of the student learning experience more meaningful. This shows that the use of instructional media that designs student environments will increase the effectiveness of learning.

The facts in the field show that the design or context used in elementary school textbooks is generally not well known by students in coastal areas. As an example design of the images used in summing numbers generally apples, cars and more.

\section{LITERATURE REVIEW}

In the curriculum stated that the emphasis of learning management is empowering students to be actively involved in building their knowledge. Furthermore, the characteristics of elementary students who are generally still concrete, the empowerment effort must be facilitated with learning resources that are appropriate to their character. This condition requires the teacher to be able and skilled to manipulate mathematical objects presented to students so that they are interesting and easily accepted by students. These conditions will trigger positive attitudes of students towards mathematics to encourage them to be
This means that it is not yet in line with the principles of learning management in a scientific approach. Elementary school level which is seen as laying the foundation of mathematical knowledge should have good mathematical understanding skills, in order to be able to understand higher mathematics. The facts in the field show that the design or context used in elementary school textbooks is generally not well known by students in coastal areas. As an example design of the images used in summing numbers generally apples, cars and more. This means that it is not yet in line with the principles of learning management in a scientific approach. Elementary school level which is seen as laying the foundation of mathematical knowledge should have good mathematical understanding skills, in order to be able to understand higher mathematics. In connection with this, it is deemed necessary to improve learning by the use of media in the design of the student environment.

Noting the facts of learning activities especially in coastal elementary schools that have not fully characterized the scientific approach, and the advantages of utilizing the characteristics of the student's environment as a design or learning resource, it is interesting to study more deeply through a study. In this respect, the purpose of this study is to assess the effectiveness of learning using media that design characteristics of the coast and its impact on the ability of students' number sense.

actively involved in learning. Bruner (in Hudojo, 1981) suggests that the best way for a student to start learning about concepts, principles or rules in mathematics is by constructing the concept, principle or rule itself and better yet if the student uses real contexts that are they experienced in formulating these ideas. This indicates that for elementary, math learning activities should be realized by using the media with their environmental design. The Transfer of knowledge through real activity students makes them understand what it means to learn, benefit, in what status they are, and how to achieve it. in this way, 
they will feel the need for that knowledge as a provision for their lives later, thus triggering the growth and development of students' mathematical dispositions in looking at mathematics. If their disposition grows, then along with this they will be encouraged active learning, better learning outcomes that lead to the achievement of the effectiveness of learning.

In constructivist theory, it is stated that knowledge is actively developed by students under teacher intervention. For learning activities to run well, low-grade students need to be facilitated with learning resources and media that are appropriate to their characteristics, such as using media that design their environment. Speaking of media definitions, the word, "media" is the plural form of "medium", which comes from the Latin "medius", meaning "middle". In Indonesian, the word "medium" can be interpreted as "between" or "medium". So the definition of media tends to mean delivering / forwarding information (messages) from information sources (message providers) to the recipient of the message or information.

Furthermore, from several sources such as Smaldino, (2012), the American Association of Education and Communication Technology (AECT), Gerlach \& Ely (1971) (in Arsyad (2010), it can be summarized that learning media is a form, container, facility, which is used by educators, to convey messages (material) to educated students so that they can be accepted properly.

The above statement gives the importance of media in learning. Related to this, Wina (2009), Rusman (2013), Sadiman, et al (2010), provide a limitation that the importance of media in learning is: (1) arousing motivation; (2) improve the understanding of the students to the teaching materials; (3) easy to understand because it is more concrete; (4) increase student curiosity; (5) attract and enlarge students' attention to the subject matter; (6) provides a learning experience that is difficult to obtain in other ways

Number sense is one of the basic abilities of mathematics, which is essential in the process of mathematics (NCTM, 2000). This means that the ability of number sense is used in almost all mathematical problems. However, in the school mathematics curriculum, the ability of number sense has not been stated explicitly, so it does not become an emphasis in learning numbers. Therefore it can be understood if the ability of student number sense tends to be poor. Sood and Mackey (2015) stated that the number sense serves as a foundation for understanding the concept and formal mathematics ability. So with the good number sense ability for elementary school students, it is hoped that students can succeed in solving mathematical problems.

Talking about number sense until now there has not been obtained an agreement because mathematicians still have many different views. Related to the understanding of number sense in NCTM stated:

" Number sense relates to having an intuitive feel for number size and combinations as well as the ability to work flexibly with numbers in problem situations in order to make sound decisions and reasonable judgments. It involves being able to use flexibly the processes of mentally computing, estimating, sensing number magnitudes, moving between representation system for number, and judging the reasonableness of numerical result."

The statement means that number sense relates to the ability of intuition about the magnitude of numbers and their combinations, as well as the ability to work with numbers in flexibly solving problems accompanied by plausible reasons. This ability includes flexibility in the process of counting without tools, estimation, knowing the number of numbers, being able to model a problem into a mathematical model, and being able to solve problems with the right reasons.

Reyes (1992) states that "Number sense refers to a person's general understanding of numbers and operation along with the ability to use this understanding in flexible ways to make mathematical judgments and to develop useful strategies for solving complex problems." This opinion means that the number sense refers to the ability of a person's general understanding of numbers and their operations to flexibly solve mathematical problems and to develop powerful strategies to solve complex mathematical 
problems.

Based on expert opinion submitted can be said that the number sense is an understanding of the number and the number associated with the meaning of the number, the relationship between the number and operation number. In line with this interpretation, the NCTM (1989) gives a characteristic number consisting of number sense meaning, relationship number, magnitude number, operation number, and number referent.

In line with NCTM Mcintosh, Reys \& Reys, 1992 stated that in general there are five components to measure the ability of number sense, namely:

1) Understanding the meaning of numbers, number operations, and relationships between numbers.

2) Ability to use a variety of representations of numbers and number operations.

3) Recognizing the relative size of numbers.

4) Able to decipher and rearrange numbers flexibly.

5) Being able to decide wisely from the results of calculations through different strategies.

Based on the measurement of number sense indicators outlined and given that this study was conducted in grade II elementary school students, the measurement of number sense in this study is limited to the meaning of numbers, representation of numbers, relationships between numbers, number operations.

Teachers as a director in the learning management should know if the learning run has been effective or not. This is important so that the effort to teach students to meet the target, considering the teacher's task is not merely to teach how to learn but also to be able to ensure that the transfer of knowledge that do effectively

Talking about the understanding of the effectiveness of learning, it should be parsed from the words forming it, namely effective and learning. Effectiveness comes from effective basic words which according to the Big Indonesian Dictionary (2007) have meaning effects, impacts, consequences or can bring results. Effectiveness is the activity, usability, suitability in an activity or a situation that indicates the extent to which the plan can be achieved. The more plans that can be achieved, the more effective these activities are so that the word effectiveness can also be interpreted as the level of success that can be achieved from a particular way or effort in accordance with the objectives to be achieved.

While learning can be defined as a process of interaction between the elements of learning in order to achieve the learning objectives. Thus the effectiveness of learning can be interpreted as the level of success in learning management based on planning and learning objectives that are set. This statement implies that the effectiveness of learning involves two main things namely the process in which there are teacher activities in the management of learning and student activities and learning outcomes.

Slavin (2000) suggests the effectiveness of learning can be measured from four indicators namely:

1) The quality of learning, it means how much is the level of information presented so students easily accept it

2) The suitability of the level of learning, it means the extent to which the teacher can ensure the level of readiness of students accepting new material

3) Incentives, it means how much effort the teacher motivates students to complete or do the tasks and study the material provided,

4) Time, which is means the time needed to complete learning activities. Effective learning if students can complete lessons following the specified time

Furthermore, Eggen and Kauchan (Mattoalinag 2015) suggested that the effectiveness of learning is characterized by the activeness of students in learning, especially in organizing and finding information. Therefore, there is a direct correlation between student activity and learning effectiveness. Surya (Aqsa, 2015) suggests the effectiveness of learning is characterized by (1) successfully delivering students to achieve learning goals; (2) providing an attractive learning experience, involving students actively to support the achievement of learning objectives, (3) having goals that support the teaching process.

Based on the limitations associated with 


\section{PRIMARY : JURNAL PENDIDIKAN GURU SEKOLAH DASAR \\ VOLUME 9 NOMOR 6 DESEMBER 2020}

ISSN: 2303-1514 | E-ISSN: 2598-5949

measuring the effectiveness of learning, it can be summarized indicators of learning effectiveness, namely: (1) management of learning by teachers based on the level of student motivation by the teacher, the level of preparation of students to start learning by the teacher, the level of student organizing in learning by the teacher; (2) student involvement in learning; (3) the appropriateness of time spent with that planned; (4) achievement of learning objectives.

Based on the above limitations, the effectiveness of learning in this study is based on the following aspects and indicators:

Table 1. Aspects and Indicators of Learning Effectiveness

\begin{tabular}{|c|c|}
\hline Aspect & Indicators \\
\hline Teacher Management & 1. Motivating students by the teacher (G1) \\
\hline Learning & 2. Getting students to start learning (G2) \\
\hline & 3. Organizing students in learning (G3) \\
\hline & 4. Encourage active students in learning (G4) \\
\hline & 5. Use of time (G5) \\
\hline Student Activity & 1. Student involvement in learning (S1) \\
\hline Learning Objectives & $\begin{array}{l}\text { 1. Achievement of learning objectives stated by passing grade } \\
\text { achievement }\end{array}$ \\
\hline
\end{tabular}

\section{RESEARCH METHODS}

This study was a quasi-experimental study with research subjects consisting of grade II elementary school students in Sungai Apit District Siak Regency 2016/2017 school year consisting of 2 classes divided into experimental and control classes. The data collection instrument is a learning observation sheet for collecting and managing learning by teachers and student activities in learning. Whereas the ability of number sense is collected using tests. Observation sheet which is based on aspects of learning effectiveness measurement and test which is based on the curriculum in 2013 and limit indicators specified number sense.

Data on learning management and student activities are collected by giving an assessment by the observer using a Likert scale, which is a value of 4 for very good, 3 good, 2 less good and 1 not good. In relation to the rating scale used, a range of assessment results and their categories is set as contained in Table 2.

Table 2. Range and Categories of Learning Management Assessment

\begin{tabular}{cc}
\hline Range & Category \\
\hline $\mathrm{X}>3.26$ & Very Good \\
$2,51<\mathrm{X}<3,26$ & Good \\
$1,75<\mathrm{X}<2,50$ & Less Good \\
$\mathrm{X}<1,75$ & Not Good \\
\hline
\end{tabular}

In line with the range and categories of aspects of measurement of learning effectiveness that are determined, learning is said to be effective if all aspects of the assessment of learning management and student activities in learning are in good categories, and the number of students achieving passing grade (70) is at least $75 \%$. 


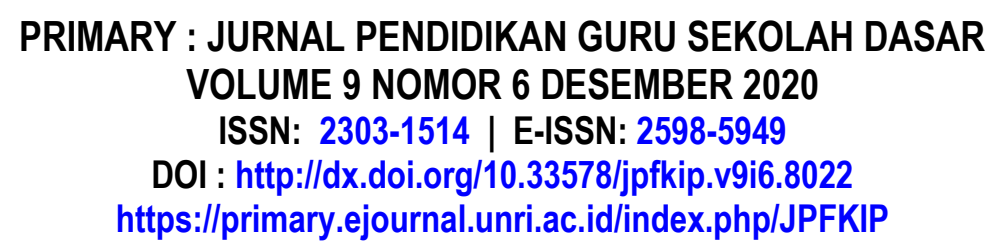

\section{RESULT AND DISCUSSION}

Based on observations made during the

observers, data showed on average. implementation of learning research by two

Table 3. Average Assessment Results of Learning Management

\begin{tabular}{ccccccccccc}
\hline \multirow{2}{*}{ Aspect } & \multicolumn{1}{c}{ Average } & Total & \multirow{2}{*}{ Category } \\
\cline { 2 - 8 } & 1 & 2 & 3 & 4 & 5 & 6 & 7 & 8 & Average & \\
\hline G1 & 2.5 & 3 & 2.5 & 3 & 2.5 & 3 & 3 & 3 & 2.81 & B \\
G2 & 3 & 3 & 3 & 2.5 & 2.5 & 3 & 3.3 & 3 & 2.87 & B \\
G3 & 2.5 & 3 & 3 & 2.5 & 3 & 3.5 & 3 & 3.5 & 3 & B \\
G4 & 3 & 2.5 & 2.5 & 3 & 2.5 & 3 & 3 & 3 & 2.81 & B \\
G5 & 2 & 2,5 & 3 & 2 & 2.5 & 3 & 2.5 & 3 & 2.56 & B \\
S1 & 3 & 3 & 3.5 & 3 & 3 & 2.5 & 3 & 3 & 3 & B \\
\hline
\end{tabular}

Based on the data contained in Table 3, information is obtained that the assessment of all aspects of learning management and student activities in learning is in a good category. This shows that from the management aspect of learning activities students meet the criteria of learning effectiveness.

Then based on the results of the assessment of students' number sense abilities obtained facts as contained in Table 4.

Table 4. List of Cumulative Frequencies for Number Sense Score

\begin{tabular}{ccc}
\hline Range & Total Cumulative Frequency & $\begin{array}{c}\text { Percentage of Cumulative } \\
\text { Frequencies }\end{array}$ \\
\hline $40<\mathrm{X}<50$ & 3 & 10 \\
$50<\mathrm{X}<60$ & 5 & 16.7 \\
$60<\mathrm{X}<70$ & 8 & 26.7 \\
$70<\mathrm{X}<80$ & 17 & 56.7 \\
$80<\mathrm{X}<90$ & 22 & 73.3 \\
$90<\mathrm{X}<100$ & 30 & 100 \\
\hline
\end{tabular}

The facts in the table show that the cumulative frequency of students in class interval three is 8 students or $26.7 \%$ of the total number of students. This shows that the number of cumulative frequency of students who got grades after class interval three as many as 22 people or $73.3 \%$. Thus, referring to the limits of the effectiveness of learning aspects of passing grade can be said to meet the specified criteria.

Based on the results of the analysis of learning management and the achievement of passing grade as described above, it can be said that the implementation of learning using coastalbased media meets the learning effectiveness criteria. This means that applied learning strategies are effectively used in learning for elementary students who are in the coastal area.

Furthermore, to see the impact of learning on the ability of student number sense analyzed with inferential statistics, where the calculations are described in the following table. 


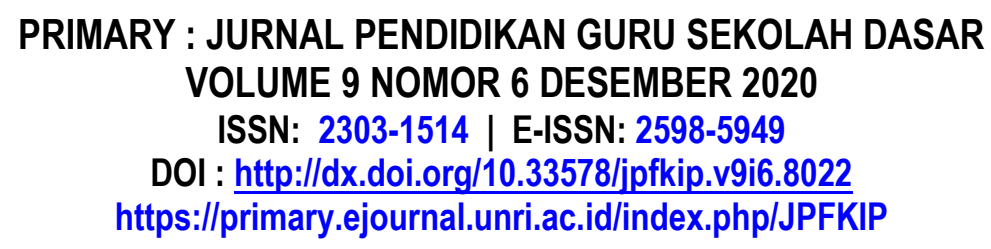

Table 5. Recapitulation of Student Number Sense Data Description

\begin{tabular}{|c|c|c|c|c|c|c|c|c|}
\hline \multirow{2}{*}{$\begin{array}{c}\text { Data } \\
\text { Source }\end{array}$} & \multirow{2}{*}{ Control } & \multirow{2}{*}{ Exp } & \multicolumn{3}{|c|}{ Homogeneous Test } & \multicolumn{3}{|c|}{ Average Test } \\
\hline & & & $\mathrm{F}_{\mathrm{h}}$ & $\mathrm{F}_{\mathrm{t}(0.01)}$ & $\begin{array}{c}\text { Remark } \\
\mathrm{s}\end{array}$ & $t_{h}$ & $\mathrm{t}_{\mathrm{t}(0.05)}$ & Remarks \\
\hline $\mathrm{N}$ & 32 & 30 & & & & & & \\
\hline Average & 7,3 & 4,2 & 2.16 & 2.18 & Ho & 41.3 & 1.64 & Ho rejected \\
\hline Std. Dev & 0.24 & 0.31 & & & accepted & & & \\
\hline
\end{tabular}

Based on the facts contained in the table above obtained information that the results of hypothesis testing reject Ho. Then by looking at the average number of scores of students in the experimental group is higher, it can be said that the application of learning using coastal-based media positively contributes to the ability of student number sense.

\section{Discussion}

The use of students' environmental designs as learning resources is essentially in line with the paradigm of mathematics learning because mathematics is the activity of every human being. It can be said that mathematics is an activity of human life so that mathematics is always built from the environment or nature of students. In line with this paradigm, the results of the study show that the application of learning using media designed by the student environment contributes well to the quality of learning and student learning outcomes.

The facts show that learning using the design tools of the coast meets the criteria for effective learning. This shows that the teacher can carry out learning following planning and achieve learning objectives. On the other hand, this learning can also encourage students to be actively involved in building their learning experiences.

Some of the results of previous studies that are in line with the results of this study include, Saragih (2015) in his research stating that learning mathematics by using a mini Lab on the topic of introduction of flat shapes meets the criteria of learning effectiveness. Annisa Al Karimah (2017) in her research stated that the effectiveness of instructional media based on interactive multimedia tutorial models on the subject lines and angles in class VII SMP / MTs included in the category of very effective. Ma'rifatul Ula (2019) in his research results concluded that mathematics learning using discovery learning models with comic media in class VII-B students of SMP Negeri 7 Surabaya was effective.

Although the results of this study indicate that the learning applied meets the effective criteria, it needs to be studied further considering the aspects that are considered not optimal. One aspect in question is the involvement of students in learning. The fact that students' activities in developing learning experiences obtained an average rating of 2.56 and is in a good category, shows that the active role of students in learning is far from optimal. This shows that the learning process that the teacher has built has not been able to provide optimal facilities for students to play an active role in building their learning experiences.

If we pay attention to the activities of teachers in encouraging students to be active in learning, which obtains a value of 2.81 with good categorization can be said to be not optimal. This means in line with aspects of student involvement in learning. That is, the weak efforts of the teacher in encouraging students to be active in learning have an impact on optimizing their role in building their learning experiences. This means that teachers' efforts to encourage students in learning that use media to design student environment areas have a real impact on student involvement in building their learning experiences.

Related to student learning outcomes, the fact shows that as many as $73.3 \%$ of students reach the passing grade set. The impact of this learning means that the learning process that emphasizes the role of students has the potential to achieve the learning objectives set. Besides, the results of 
inferential tests that show that the application of learning using media designed by the student's environment have a significant impact on the ability of student number sense. This fact shows that learning by using environment-based design contributes well to student learning outcomes.

Learning by utilizing the student environment provides opportunities for students to learn without eliminating habits or cultures that have formed in their life activities, so they feel that learning mathematics does not have to give up their existing habits. Such learning conditions make them feel comfortable, more meaningful to provide a PAKEM learning nuance. To create an atmosphere of a scientific learning process that is

\section{CONCLUSIONS AND RECOMMENDATIONS}

Based on the results of data analysis, it can be concluded: (1) the application of learning using the effective coastal design is applied in mathematics learning in elementary coastal areas; (2) there is an increase in the ability of number sense coastal elementary school students who are taught by learning using coastal-based media.

Referring to the management of learning related to the implementation of this research, some suggestions are proposed if similar research is carried out, namely:

1) Structuring the use of instructional media that leads to formal mathematics. This means

\section{REFERENCES}

Annisa, A. K. (2019) Efektifitas Media Pembelajaran Matematika Menggunakan Software Animasi Berbasis Multimedia Interaktif Model Tutorial Pada Materi Garis Dan Sudut Untuk Siswa Smp/Mts Kelas VII. Jurnal Penelitian Pembelajaran Matematika Sekolah (JP2MS), 1(1). 147-155.

Aperapar, P.S., dan Hoon, T. S. 2011. An Analysis of Number Sense and Mental Computation in the Learning of Mathematics. Jurnal Pengajaran MIPA16 (1), 148-154.

Kurikulum 2013 Lebih Unggul dari Kurikulum Sebelumnya, (Online), (http://www.kaltimpost.co.id/berita/detail/19 889/kurikulum-2013-lebih-unggul-daripada- in line with the actual environment of students they experience.

If you see an observer's description of the assessment of learning management and the active role of students it can be said to be not optimal, such as time management, organizing students in learning. The lack of optimal management of learning is partly due to factors teachers and students who are not accustomed to applying learning based on student empowerment. This indicates that it takes sufficient time for teachers and students to become accustomed to learning that emphasizes the role of students in building their knowledge.

starting to build knowledge by using mediabased characteristics of the student's environment must end on learning media that are formal. This is so that students can transfer their learning experience that is built through real design media, to formal mathematical abstract with tiered contrast.

2) In managing learning, students should be grouped with attention to their closeness so that interaction between students is better. In this study, students were grouped based on the closeness of their seats so that some students were still ashamed to interact with friends.

kurikulum-sebelumnya.html), diakses 16 September 2013.

Ma'rifatul, U., dkk (2017). Fefektivitas Pembelajaran Discovery Learning Dengan Media Komik Pada Pembelajaran Garis Dan Sudut Di Smp Negeri 7 Surabaya. Jurnal Matematika dan Pendidikan Matematika, 4(1). 75-80.

Gravemeijer, K.P.E. (1994). Developing Realistic Mathematics Education. Utrecht: CD-b Press. The Netherlands.

Hamzah. (2011). Belajar Dengan Pendekatan PAILKEM. Jakarta: Bumi Aksara. 
Hendriani. (2004). Penggunaan Lingkungan Sebagai Sumber Belajar. Depdiknas: PPPG IPA.

Hudoyo, H. (1998). Pembelajaran Matematika Menurut Pandangan Konstruktivistik. Makalah disajikan pada Seminar Nasional Upaya-upaya Meningkatkan Peran Pendidikan dalam Era Globalisasi. PPS IKIP Malang. Malang, 4 April 1998.

Reys, R., Reys, B., Emanuelsson, G., Johansson, B., McIntosh, A., \& Yang, D. C. (1999). Assessing number sense of students in australia, sweden, taiwan, and the united states. School Science and Mathematics, 99(2),

61-70.

http://dx.doi.org/10.1111/j.19498594.1999.tb17449.x

Rey,s, R.E. (1998). Helping Children Lear Mathematics. (5th ed). USA: Ally and Bacon.

Tuckman, Bruce W. (1978). Conducting Education Research. San Diego: Harcourt Brace Jovanovich.

Thiagarajan, Sivasailam; Sammel, Dorothy S; Melvyn L. (1989). Instruction Development For Trining Teachers of Exeptionan Children. Minnessota : Indiana University. 